\title{
Justice in a One-Party African State: The Tanzanian Experience. A Reply to Peter's Rejoinder
}

\author{
By Umesh Kumar
}

I would like to reply to Chris Maina Peter's comment published under the title "Justice in a One-Party State African State: The Tanzanian Experience - A Rejoinder" in VRU 20 (1987), page 235.1 I would be brief and limit myself to the major issues as the whole thing has become rather dated. It would be churlish on my part to deal with typographical errors, particularly when they do not affect the substance or direction of my article. 2

In the first part of my reply, I will deal with the issues surrounding one-party state. Second part will deal with judiciary and the administration of justice. Last part is the conclusion.

\section{One-Party State}

The main thrust of my article was to explore, on a theoretical and operational level, the concept of party supremacy and its implications for the administration of justice taking the Tanzanian system as a paradigm. I began with a hypothesis that if one were to look for a single, most significant factor for a rash of one-party states in Africa, it would invariably be the emergence of the nationalist party that opposed the colonial rule into a national party ruling the country after independence. But then why did a nationalist movement like TANU transform itself into the sole legal party in Tanzania? My thesis was that, in retrospect, it has invariably been the result of a conscious and deliberate political choice of the charismatic leaders like Nyerere and not so much of the party.

Peter states that the proposal to turn Tanzania into a one-parte state came from the party President in 1963 and in the same year the party's National Executive Committee (NEC) "made the decision" (page 244)3. But he did not mention that the party President was no other than Nyerere and that there is considerable authority for the proposition that Nyerere

1 My initial article appeared under the title "Justice in a One-Party State: The Tanzanian Experience" and was published in VRÜ 19 (1987) at page 255.

2 I would point out two in particular in my article: In footnote 7 on page 256, the date ought to have been 26th April 1964 and in footnote 56 on page 266, Jaji Kiondozi ought to have been Jaji Kiongozi. None of these affect in any way the substance or direction of my paper.

3 Figures in brackets refer to Peter's rejoinder as published in VRÜ 20 (1987), page 235, throughout this paper. 
himself was the initiator and moving force behind this decision and that NEC merely went along with it. 4

To test my hypothesis I compared the Tanzanian situation with India and concluded that it was the charismatic party leadership which șought and established a competitive, pluralist and democratic political system in India. Peter finds my comparison between the development of the nationalist movements "into national parties in India and Tanzania both illconceived and to a large extent ahistorical". Peter contends that charismatic leadership of Gandhi was very different from Nyerere and brings in "religious squabbles" between Hindus and Moslems which led to the partition of India (pp. 238-240).

I am a bit surprised by all this because there was absolutely no mention of either Gandhi or "religious squabbles" in my article. The comparison between Nyerere and Gandhi is as farfetched as the "religious squabbles" were to the establishment of a pluralist constitutional democracy in India. Peter does not realize that when the decision to establish a competitive, pluralist political system in India was taken Gandhi was not even alive and "religious squabbles" were a thing of the past! 5

TANU, as a political party and as a nationalist movement, bears comparison with Indian Congress Party. The Congress Party, like TANU, rose from a nationalist movement and like TANU swept the polls. Msekwa has claimed that central to the perception of Nyerere that a "democratic, one party state" was the best political altemative in the Tanganyikan context, given its poverty and under-development, was the political reality that more or less since 1959, Tanganyika had been under a de facto one-party system as shown by the electoral results. It has been claimed that this, in effect, meant a de facto "disenfranchisement" of voters.6 Pratt states7 that in the elections held on 30th August 1960 TANU's victory was "overwhelming". TANU candidates were unopposed in 58 of the 71 seats. They lost only 1 of the remaining 13 seats. In 1962-63 Local Government elections as many as 350 TANU candidates for 356 seats were returned unopposed. Peter surprisingly claims that it is "misleading" for me to conclude that there was nor perceptible opposition to

4 See page 257-258 and notes 14 and 15 of my article, where this point has been discussed.

5 The decision conceming a competitive, pluralist, democratic system is incorporated in the Constitution of India, which was drafted by the constituent assembly.

6 See Msekwa, P., The Doctrine of the One-Party State in Relation to Human Rights and the Rule of Law, UTAFITI, Vol. 3, No. 2, 1978, at 397-398.

7 Pratt, C., Critical Phase in Tanzania, 1945-67, Cambridge 1976, at page 55. 
TANU (page 243). ${ }^{8}$ But Peter himself concedes that TANU was a "dominant" party (page 243) and such opposition parties as were there were "tiny" (page 244 and quote from Pratt)!

That disenfranchisement argument could well have been applied in India as well to establish a one-party state. But the charismatic political leadership of the Congress Party 9 consciously strove to establish a competitive party system even though, like Tanganyika, there was a nationalist movement which transformed itself into a national party, and which swept the electoral polls. In effect, there indeed was a de facto "disenfranchisement" of voters like Tanganyika, in a large number of constituencies. In short, the charismatic party

8 It was then not difficult to establish political parties, and under these circumstances the existence of a few "tiny" opposition parties can not be a reliable yardstick to measure opposition. One can not naturally follow from the mere fact of existence of such "tiny" opposition parties that they enjoyed much political support. And if electoral triumph is taken as a yardstick, one is not too sure of these "tiny" opposition parties had much of a chance. Lastly, I did not say there was no opposition but no "perceptible opposition".

Peter laments that the such opposition as it was there was "forcefully pushed out of existence" (page 244). But was it not foreseen? In this context, it may be worthwhile to quote Nyerere, who wrote in the British Weekly Tribune in June 1960: "The notion that democracy requires the existence of an organized opposition to the govemment of the day is false. Democracy requires only freedom for such an opposition, not the existence of it. ... The nationalist movements are going to be very powerful, indeed; they will control the govemment ... without there being any effective challenge to them from within - and any challenge from outside will only strengthen them. Development of a one-party government will in fact be the inevitable result ... (A real opposition) will eventually happen and it will be brought about by a split in the nationalist organization." Doesn't one see the seeds of authoritarianism in a one party statement in this statement made as early as June 1960? Incidentally in India, the monolithic Congress Party did split more than once and this led to formation of several opposition parties.

He claims that TANU "was (and still is) in minority in comparison with the total population of the country" (page 244). I do not quite understand it. There has been no political party called TANU since 5th February 1977 when CCM came into existence. Perhaps Peter meant CCM. Since CCM is the only political party allowed by law, the question whether it is in majority or minority does not arise. The question of a party being in majority "in comparison with the total population" of a country does seem rather inapt, even if by "total population" is meant "total eligible voters' Population". Even in a competitive political system, the ruling political party may not always be in majority "in comparison with the total population". Congress Party in India which has been a ruling party for many years and for that matter Mrs Thatcher's govemment in the United Kingdom are good examples of this. I doubt of any political party in any state in Africa will qualify of Peter's criterion were to be used.

9 It did not consist of Gandhi as Peter claims. Gandhi did not identify himself as a leader of the Congress Party. Pandit Nehru was undoubtedly the most charismatic Congress leader. There were others, too. Maulana Abul Kalaam Azad, Dr. Ambedkar, Dr. Rajendra Prasad and Sardar Vallabh Bhai Patel were other Congress leaders who played a significant role in the decision to establish a pluralist constitutional order in India. 
leadership in India did not want a one party state as a conscious and deliberate choice; in Tanzania it was the opposite. 10

A second major theme of my paper concemed the relationship of the party (CCM) with the national Constitution. CCM has its own Constitution and it is not always in harmony with the national Constitution. I wrote whether the CCM Constitution controls the national Constitution in the event of a conflict is a moot question. It can be argued that the supremacy of the CCM is established by the CCM Constitution itself, the national Constitution doing no more than accepting an established fact. I contended that this argument overlooks the fact that while the CCM Constitution, being more of a political document, can establish party supremacy as a political fact, it is the national Constitution alone that can establish it as a legal fact. If rule of law has to have any role and meaning in Tanzania, party supremacy has to be subsumed under the national Constitution, not the party Constitution.

Peter concedes as much when he says that up to 1975 "there was nothing on legislation on party supremacy" and that this "situation created a new and unexpected problem, namely the enforcement of party directives in the courts of law"11 (page 247). Yet he claims on page 242 that issues "like party supremacy being a political or a legal fact have long been settled and it makes little sense to labour on them". Peter then goes on to claim that the "party Constitution is very clear on it supervisory role to the government and other state organs".

I beg to differ from Peter that if "party Constitution is very clear", the problems should be considered legally settled.12 It was this very anti-thesis - between party Constitution and national Constitution - that I was worried about. How was it then settled? Is it settled by Section 3 of the national Constitution, 1977, which stipulates that "all activities of the organs of the State" shall be conducted under the auspices of the CCM? In the Tanzanian context does it imply that the national Constitution, a legal document, is wholly subordinated to party Constitution, a political document? In my opinion, it is not that simplistic. In fact the conundrum of political fact versus legal fact may serve to explain why the political

10 The whole gamut of discussion that Peter indulges in conceming the TANU's consolidation of political power and the suppression of political opposition is not germane to my thesis at all. I fail to find an altemate explanation for the establishment of a one-party state in Tanzania in Peter's rejoinder.

11 Peter's note 35 where he cites Chief Justice P.T. Georges' observation that the national Constitution did not set the party above the organs of the State is quite instructive in this regard. That observation, however, was made in 1966. Can it be reconciled with Section 3 of the national Constitution, 1977, which stipulates that "all activities of the organs of the State" shall be conducted under the auspieces of the CCM?

12 If it was settled in this way, then why should Peter quibble regarding the "label" a decision - party or govemment - should be given. Let party Constitution control the situation and determine it (page 245)? 
decisions or directives of the National Executive Committee of the party are not sui generis legally binding; they have to undergo the process outlined in the national Constitution before they could be given the status of a legal rule. In short, the legal reach and scope of the party directives continues to be problematic for political, as well as, legal reasons. And, that appears to be so in several one party states in Africa.

My third theme was that proper procedures for the exercise of the party supremacy were not adequately delineated and I thought that was rather a serious omission. For it ought to have been obvious that not all the decisions of the party can be supreme. Some of them would be run-of-the-mill, routine decision that would scarcely have the status of supreme decisions. Some others would be supreme and binding on all state organs under Section 3 of the national Constitution. Party supremacy, thus, has to be expressed through party decisions and a distinction has to be drawn between decisions that are supreme from those that are not. Party supremacy to me means the supremacy of the decisions of the party, not the supremacy of individuals - howsoever charismatic - within the party. I thought this distinction was fundamental to the legitimacy of the party supremacy itself.

Peter calls it "hair-splitting to engage in arguments on which party decisions are supreme" (page 242). In my opinion, it is of considerable significance. The relevant decision-making process within the party has to have a considerable degree of legitimacy. If there is a significant gap between the legal theory thus perceived and the reality, then the legitimacy and even the institution of party supremacy itself in such a legal system may be open to doubt. Concern with the lack of inner democracy within the decision-making processes and structures of a party that is supreme and issues conceming legitimacy and legality of decisionmaking structures and can hardly ever be regarded as "hair-splitting".

Peters questions my statement that the party's National Executive Committee (NEC) normally abides by the ranking and nominations made by the District Conference regarding aspirants of the Parliamentary seats. He claims that actually the opposite is the case (page 240). Apart from giving one stray example taken from 1985 elections, he offers no statistical data to support his statement. Prath, for example, writes that during the first election in 1965, NEC set aside the ranking and nominations made by the District Conferences only in 16 out of 97 cases. $13 \mathrm{He}$ also tells us that in the first election Nyerere introduced the important rule that the NEC would only upset the ranking of candidates which has been made by the District Conference when the NEC agreed that there were compelling reasons why one or other of the two top names should not be put to the electorate.14 Did this change dramatically in 1980 and 1985 general elections? My discussions with several knowledgeable Tanzanians confirmed that it has not been the norm for the NEC to

13 Pratt, op. cit., page 207.

14 Pratt, op. cit., at page 205. 
disregard District Conference nominations on a large scale. ${ }^{15}$ It was never claimed in my article that NEC never overtums the District Conference recommendations. There have been several such cases but to contend that "opposite is the case", and thus the norm, does not correspond to the reality as I understand.

\section{Administration of Justice}

Some of the above themes were pursued under the rubric administration of justice. I tried to demonstrate, through the decided cases, that the judiciary on occasions has tended to show its subservience and timidity when confronted with the institutionalized party supremacy and that this may adversely affect the quality of the administration of justice. One of the cases that I discussed in this context was Ahmed Janmohamed Dhirani v. Republic Of Tanzania. 16

Peter takes issue with me over my footnote number 70 on page 270 of my article where I wrote: "In (Ahmed Janmohamed Dhirani v. Republic Of Tanzania), though the Regional Superintendent of Prisons had the detention order in his custody, he refused to accept judicial summons to appear before the High Court with the detention order. Instead, he locked the document away and went on a safari. The High Court found it 'disrespectful to the court' but did not proceed in contempt".

Peter claims that nothing of the kind happened, that I had overdramatized the situation and the "over-dramatization may also lead to contempt of court" (page 238). I beg to differ from Peter. What I wrote in my note 70 represented reality. Perhaps a good way to establish it is to quote extenso from the judgment of Maganga, J. in the said Dhirani's case:

"... the court directed a fresh summons under rule 3 to issue and that it be directed to the Regional Superintendent of Prison at Butimba. This was on 30th July 1976. The summons was taken to the Regional Superintendent of Prisons at Butimba but it was returned unserved with an endorsement that he had refused to accept the service because the summons was wrongly addressed. He told the process server that his correct title was Regional Prisons Officer, Butimba, and that the surnmons should be so addressed. His request was complied with and necessary alterations were made on summons. These were properly initialled by the District Registrar. However, the service could not be effected on either the 31st of July or on the 2nd of August 1976 because he could not be found in the office. An attempt to serve the same summons on the officer-

15 I tried phoning Mr. Kawawa, a very senior party official, for official 1980 and 1985 general election statistics but failed to get a line.

16 (1979) The Law Reports Of Tanzania No. 1. 
in-charge of Butimba Prison failed. The summons was returned unserved with an endorsement that the Regional Prisons Officer was absent from his office because he was preparing to leave for Dar es Salaam. At the same time the State Attomey informed the court that his information was that the Regional Prison Officer was absent from his office because he was preparing to go to Geita on official duty." 17

(Fresh summons was then issued which was directed to the Officer-in-charge of Butimba Prison, who appeared in person on 2nd August 1976 but did not produce the detention order.) "He filed an affidavit in reply to the summons in which, although he admitted that the applicant was at Butimba Prison he deposed that the applicant was detained and was in the custody of the Regional Prison Officer. He also deposed that although the applicant was in his actual custody, he could not produce the detention order since all such orders were being kept in a confidential registry whose keys are kept by the Regional Prisons Officer, who was on safari at the time."18

Maganga, J., commented that the Regional Prisons Officer was "aware of the existence of the detention order" and it was "in fact in his actual custody when the summons for the production of the same were presented to him on 30th July 1976". Yet he "decided to refuse service of the summons on a pretext that his title was wrongly quoted. This was despite the fact that he was aware and believed that the said summons was meant for him." Further, he "decided to lock the document away from the Officer-in-Charge of the prison despite his knowledge of the existence of these proceedings and the summons issued by this court". The "attitude of the Regional Prisons Officer must be condemned in the strongest terms and it can only be described as disrespectful to this court."19

I had the privilege of discussing the issue with one of the lawyers who was actively involved in this case. He confirmed that the evasive conduct of the Regional Prisons Officer was indeed a subject of bitter contention before the court. The court condemned the conduct in the "strongest terms" and termed it "disrespectful", yet it did not proceed in contempt. That is exactly what I wrote in my article and it is obviously wrong to accuse me of dramatizing (much less over-dramatizing) events.

I tried to argue that in essence the tussle between the expediency versus legality arguments, which takes many and varied forms, could offer a rational explanation for the occasional judicial subservience. Courts in common law jurisdictions often place a heavy emphasis on following strictly the statutory procedures laid down as a part of the requirement of the due

17 Ibid. pages 2 and 3.

18 Ibid. page 3.

19 Ibid. pages 4 and 5. 
process of law. ${ }^{20}$ Judicial review is directed not at the decisions but at the decision-making process including its proper legalization. The party and the executive may miss this distinction and may not only view it unduly legalistic but even as an attempt to challenge the supremacy of the party.

The executive plays a significant role in the appointments of judiciary throughout the commonwealth countries. Tanzania is no exception. The Chief Justice 21 in Tanzania is appointed by the President, who has considerable influence and say in the the party as well. The puisne judges are appointed by the President but in consultation with the Chief Justice. The complication factor is that in a one-party state, like Tanzania, the executive is scarcely ever immune from the influence of the party. 22 But just because executive has a hand in the appointment of key judicial personnel, can it be inferred that administration of justice as such is affected? The two instances Peter refers to in his rejoinder are instructive in this regard. One was a circular in 1973 from the Chief Justice Georges that all cases involving Ujamaa villages should be sent directly to him as he had the sole jurisdiction to entertain them. At that time, the party decision to set up Ujamaa villages had not been legislated into law and it rightly attracted uproar from other members of the judiciary. The second a public speech of the Chief Justice23 a year earlier in 1972 exhorting his colleagues, primarily in subordinate courts, to further the policies of the party and the government. The two instances could be seen as examples of a difficult relationship that judiciary in a one party state has to endure. it is very much left to the individual judges to stand up to the ideals of the rule of law.

That is not always easy. Judicial activism has its perils. It could be seen as having the overtones of politics and may accentuate by several notches the degree of vulnerability that courts must always guard against. Judicial restraint, even judicial diffidence, sould as well then be an exercise in self-preservation.

20 For example, Chief Justice in Attorney General v. Lesinoi Ndeinai and others (1980) stated that public policy requires that citizens shall not be deprived of their liberty or freedom except by due process of law.

21 I wrote in my footnote 56 that the Chief Justice of the Court of Appeal is appointed by the President. Peter points out at page 237 of his rejoinder that the Chief Justice of the High Court, who is appointed by the President, can only sit in his judicial capacity in the Court of Appeal, and not in the High Court. The point is taken but this technical distinction does not affect in any way the substance or direction of my article.

22 There are, of course, important constitutional safeguards against executive interfering with the independence of the judiciary. It is beyond the scope of this paper to discuss the merits of such safeguards.

23 That I mistakenly refer to as a circular. The quoted statement was reported in the Daily News on 26 September 1972 as pointed out by Peter (page 238). 
My references to Bill of Rights in Tanzania was hesitant and speculative. It was not in existence at that time. Peter contends that the "absence of a Bill fo Rights is a sine qua non for the smooth functioning of a one parte system" so that an undemocratic regime can freely do whatever it likes (page 249). I beg to differ. A democratic one party state can be viable provided it has three essential features: a Parliament composed largely of directly elected representatives of the people with sufficient powers to oversee the performance of the govemment and the passing of legislation, a Bill of Rights to check executive and party excesses to saf eguard the dignity and freedoms of individuals and an independent judiciary for an efficient administration of justice. In short, legal institutions are an important segment of a whole set of social arrangements and their effectiveness depends on harmonious coordination and consensus that such social arrangements are able to achieve.24

Peter is worried that the provisions of the Tanzanian Bill of Rights are not absolute, that they are riddled with exceptions. I am not aware of any Bill of Rights in any commonwealth country which does not have restrictions. Indian example is instructive in this regard. Over a period of more than three decades, Indian Supreme Court has shown how these restrictions can be overcome with judicial courage and innovation. An incredibly inspiring bill of rights jurisprudence has been built up over the years in India. Judicial activism has been blended with juridical activism to achieve a people-oriented Supreme Court notwithstanding similar or greater restraints that Tanzanian Bill of Rights has. 25 Tanzanian judges are as capable as anywhere else in the world and I have no doubts they too would rise to the challenge. This is a process; it takes time.

\section{Conclusion}

Peter contends it is "fundamentally wrong to identify problems in terms of institutions e.g. the party v. government or parliament. The important question is which classes control these institutions" (page 253).26 That could well be so in classical Marxist thinking and Peter is entitled to it. But so are others who do not and have reservations about its strategies

24 Cf. Mandel, M., Marxism and the Rule of Law, UNB Law Joumal 35 (1986) 7, 13.

25 See Baxi, Upendra, The Indian Supreme Court and Politics, 1980, Eastem Book Company, Lucknow. Even the absence of a written constitution did not deter the judiciary in Britain to control judicially executive excesses through the development of legal concepts like "illegality", "irrationality", "procedural impropriety" and very recently, "proportionality".

26 Why doesn't Peter include judicial institutions as well? 
at the practical level. ${ }^{27}$ To deny or even belittle rule of law and legal institutions including judicial institutions is a "self-fulfilling error" which not only encourages us to give up the struggle against bad laws but even to disarm ourselves before executive and party excesses. 28 That surely is not a comfortable scenario.

27 It is no accident of history that more and more states are reexamining the economic costs that the Marxist system exacts from the nation.

28 See Mandel, M., op. cit., page 20 et al. 